Josip Lasić

Filozofski fakultet Sveučilišta u Splitu

jlasic@ffst.hr

(iD https://orcid.org/0000-0001-5254-7903

Magdalena Nigoević

Filozofski fakultet Sveučilišta u Splitu

magda@ffst.hr

(iD https://orcid.org/0000-0002-9047-8408

\title{
Tvorbeni oblici etnika otoka Brača
}

Sažetak: Termin je etnik u hrvatskoj jezikoslovnoj literaturi definiran kao ,ime za stanovnika ili stanovnicu nekoga naseljenoga mjesta (ojkonima), kraja, zemlje, države i kontinenta ili osobe koja odatle potječe,,${ }^{1}$. Dosadašnja su istraživanja područja tvorbe etnika u standardnome jeziku ${ }^{2}$ i u pojedinim dijalektima ${ }^{3}$ potvrdila izrazitu dominaciju sufiksalne tvorbe. Zabilježeno je u standardnome jeziku da u njoj sudjeluje osamdeset i šest (86) sufikasa za muški te dvadeset i jedan (21) sufiks za ženski rod. U radu se predstavlja, a potom analizira korpus etnika naseljenih mjesta otoka Brača. Izrađen je nakon provedenoga terenskoga istraživanja u rujnu 2018. i ožujku 2019. godine. Na otoku Braču zabilježena su dvadeset i dva (22) naseljena mjesta, a izvedeno je četrdesetak etnika za ženski i za muški rod. U analizi se tvorbenih oblika etnika ovjerila činjenica o višeslojnoj dijalekatskoj različitosti pa će se u radu predstaviti terenski obrađena dijalekatska posebitost vidljiva kroz zanimljive postupke tvorbe za ženski i za muški rod. Brački su etnici za potrebe ovoga rada zabilježeni, ovjereni, popisani i obrađeni na razini tvorbe s primarnim ciljevima: očuvanje od zaborava (jer su neka bračka mjesta danas gotovo napuštena) kao prvi, i usustavljivanje bračkih etnika s opisanim modelima tvorbe etnika u standardnome jeziku kao drugi cilj istraživanja.

Ključne riječi: etnici, tvorba etnika, dijalekt, govor Brača

\footnotetext{
${ }^{1}$ Stjepan Babić, „Tvorba etnika u dijalektima i u hrvatskom književnom jeziku,“ Onomastica Jugoslavica, br. 6 (1976): 146.

2 Eugenija Barić, Mijo Lončarić, Dragica Malić, Slavko Pavešić, Mirko Peti, Vesna Zečević i Marija Znika, Hrvatska gramatika (II. promijenjeno izdanje) (Zagreb: Školska knjiga, 1997); Josip Silić i Ivo Pranjković, Gramatika hrvatskoga jezika za gimnazije i visoka učilišta (Zagreb: Školska knjiga, 2005).

${ }^{3}$ Petar Šimunović, Rječnik bračkih čakavskih govora (Supetar: Brevijar, 2006); Ankica Čilaš Šimpraga i Ivana Kurtović Budja, „Etnici i ktetici u kajkavskom narječju,“ Rasprave: C̆asopis Instituta za hrvatski jezik i jezikoslovlje, vol. 35, br. 1 (2009): 35.
} 


\section{Umjesto uvoda: odrednice mjesto, mještanka i mještanin ${ }^{4}$}

Otok Brač jezično je i povijesno zanimljiv brojnim istraživačima. Dosadašnja su znanstvena i terenska istraživanja jezične povijesti i dinamične dijalektološke slike otoka, usporede li se pritom sa sličnim istraživanjima ostalih prostora srednje Dalmacije, bogata i temeljita ${ }^{5}$. Smješten u središnjemu dijelu Dalmacije, uz otok je Šoltu, najbliži gradu Splitu. Prema arheološkim je nalazima otok Brač možda najstarije čovjekovo prebivalište na prostoru Dalmacije ${ }^{6}$.

Središnji je dio otoka prvi naseljen, uz današnje naselje Nerežišća u unutrašnjosti otoka, dok će pojas uz more, gdje danas prepoznajemo većinu naseljenih mjesta, postati naseljen tek krajem 17. i početkom 18. stoljeća. Stvaraju se od toga vremena uglavnom uzmorska naselja, $\mathrm{u}$ većini dalmatinskih govora prepoznatljiva kroz odrednicu misto. Zanimljiva su to mista po mnogočemu, a ponajprije zbog premreženosti čakavskoga i štokavskoga na zaokruženome prostoru najnaseljenijega srednjodalmatinskoga otoka. U radu se stoga terminološki koristi jednoznačno oznaka mjesto za opis onoga što je u standardnome jeziku prepoznatljivo kao naselje (naseljeno mjesto), a kao određeni imenovani prostor koji ima svoje stanovnice (mještanke) i stanovnike (mještane). Terenskim su radom (listopad 2018. i ožujak 2019.) zabilježena i popisana uporabna jezična rješenja za imenovanje (su)mještanki i (su) mještana (etnika ženskih i muških osoba) iz dvadeset i dva (22) bračka mjesta. Donose se u nastavku i ostali rezultati prikupljeni terenskim radom s ciljem usporedbe (i mogućega usklađivanja) tvorbenih modela etnikinja i etnika bračkih mjesta sa standardološkim rješenjima koja nude postojeći gramatički priručnici.

\footnotetext{
${ }^{4}$ Dalmatinski govori, posebice oni uz naselja bliže moru, značenjem razlikuju: (1) misto (je) 'naselje', (2) mišćanka (je) 'stanovnica (nekoga) naseljenoga mjesta' i (3) mišćanin (je) 'stanovnik (nekoga) naseljenoga mjesta'.

${ }^{5}$ U prvome redu dijalektološka i dijakronijska istraživanja akademika Petra Šimunovića u kapitalnome Čakavisch-deutsches Lexikonu (1979-1983; s Hraste, M.), zatim u Rječniku bračkih čakavskih govora (2006) te kasnije u istraživanjima mlađe generacije jezikoslovaca primjerice u radovima Siniše Vukovića (2006) i Filipa Galovića (kontinuirano od 2012. do danas).

${ }^{6}$ Spilja je Kopačina (između mjesta Donji Humac i Nerežišća) najstarije poznato čovjekovo obitavalište na otoku Braču, tragovi su života iz razdoblja od 8. do 3. stoljeća pr. Kr. Vidi: Nikola Vukosavljević, Zlatko Perhoč, Božidar Čečuk i Ivor Karavanić, „Kasnoglacijalna industrija lomljenog kamena pećine Kopačine,“ Vjesnik za arheologiju i povijest dalmatinsku, vol. 104, br. 1 (2011): 9-10.
} 


\section{Etnik, etnonim i etnoid u hrvatskoj jezikoslovnoj praksi}

Dugo se već među jezikoslovcima postavlja pitanje kako je i je li moguće jednoznačno odrediti i uskladiti terminologiju koja se odnosi na imena za stanovnice (mještanke) i stanovnike (mještane) pojedinoga mjesta. Brozović koristi širu odrednicu 'naziv za stanovnike gradova i gradića' ${ }^{7}$. Težak pak dvadesetak godina kasnije koristi odrednicu etnik (nerijetko etnonim) u značenju 'naziv za stanovnika ili stanovnicu nekoga naseljenog toponima' ${ }^{8}$ čime proširuje Brozovićev opis i na ona imena koja se odnose na stanovnike mjesta manja ili koncepcijski različita od onoga što se prepoznaje kao grad, odnosno gradić. Napominje kako je za izvođenje standardoloških oblika etnika iz imena mjesta vrlo pouzdan model uzimanje onoga oblika koji je najučestaliji u govoru lokalnoga stanovništva jer su ,stanovnici pojedinoga mjesta najpozvaniji

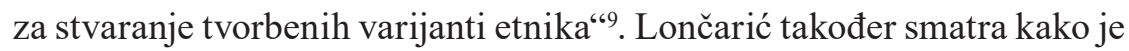
lokalno stanovništvo najbolji kreator za imenovanje (su)mještanki i (su) mještana kao i u određivanju oblika koji će u konačnici biti (is)korišten za potrebe određivanja standardnoga oblika ${ }^{10}$. Kod jezikoslovaca, očito je, dominira stav kako je osluškivanje govora lokalnoga stanovništva pri gradnji oblika etnika najpouzdaniji način uspostave kriterija za korištenje etnika u standardnome jeziku ${ }^{11}$. Novija će istraživanja također potvrditi kako je lokalni govor osnova za oblikovanje etnika ${ }^{12}$.

Tvorbu je etnika u standardnome jeziku, ali uglavnom na primjerima preuzetim iz niza dijalekata, najtemeljitije opisao Babić. Sredinom je sedamdesetih godina prošloga stoljeća dao detaljan opis etnika, njihov položaj u standardnome jeziku i u pojedinim dijalektima. Sufiksalnu je tvorbu istaknuo kao najbrojniju (i najplodniju) razlažući tvorbu kroz podjelu etnika za muške i etnika za ženske osobe ${ }^{13}$. Etnike definira kao „,ime za stanovnika ili stanovnicu nekoga naseljenoga mjesta (ojkonima), kraja, zemlje, države i kontinenta ili osobe koja odatle potječe, a ta

\footnotetext{
${ }^{7}$ Navodi grad i gradić pa se pod gradić uvrštavaju naselja dalmatinskoga areala koja prepoznajemo u odrednici misto/mjesto (bilo da su u unutrašnjosti ili uz more). Vidi: Dalibor Brozović, „Neki etnici u novom izdanju »Pravopisa«,“Jezik, vol. 1, br. 2 (1952): 54.

${ }^{8}$ Stjepko Težak, „O temi: toponimi, etnici i ktetici u književnom jeziku,“ Jezik, vol. 22, br. 1 (1974): 1-2.

9 Stjepko Težak, „Etnici i ktetici u pravopisnom rječniku,“ Jezik, vol. 21, br. 2 (1973): 52-53.

${ }^{10}$ Mijo Lončarić, „Etnik od Koprivnica,“ Jezik, vol. 21, br. 2 (1973): 56-57.

${ }^{11}$ Petar Skok, „Tvorba imena stanovnika od imena naselja i oblasti,“ Jezik, vol. 2, br. 3 (1953): 65-66.

12 Šimunović, Rječnik bračkih čakavskih govora; Čilaš Šimpraga i Kurtović Budja, „Etnici i ktetici u kajkavskom narječju“.

${ }^{13}$ Babić, „Tvorba etnika u dijalektima i u hrvatskom književnom jeziku,“ 147.
} 
definicija jednako obuhvaća uz etnike i etnonime (imena naroda i narodnosnih skupina),.. Etnici su, dalje nastavlja, „, standardnome jeziku njegov najneustaljeniji dio,,${ }^{14}$. Tu neustaljenost potvrđuju i danas brojni zabilježeni etnici koji svojim tvorbenim oblikom teško ulaze u okvire standardnoga jezika ${ }^{15}$.

U novijim se istraživanjima također naglašava razlikovanje etnika kao 'imena stanovnika kojega naselja ili predjela' od etnonima kao 'imena naroda, nacionalnosti', a jezikoslovno područje u kojemu se najbolje razlikuju etnici od etnonima je onomastika ${ }^{16}$. Nekoliko godina ranije isto navodi Šimunović definirajući etnike i etnonime u Uvodu $u$ hrvatsko imenoslovlje ${ }^{17}$. Za suvremena promatranja etnika Hrvatski jezični portal (pokratom HJP) donosi definiciju 'naziv stanovnika naseljenog mjesta, kraja, regije, zemlje ili kontinenta (npr. Splićanin)', etnonim je, pak, 'ime etničke zajednice, pripadnika naroda i narodnosnih skupina', a etnoid je 'naziv skupine stanovnika prema zemljopisnom pojmu (npr. otočanin, primorac, goranin)'. Vidljivo je da u dosadašnjoj hrvatskoj jezikoslovnoj praksi dominira odrednica etnik i taj se oblik za predstavljanje oblika bračkih etnika koristi jednoznačno - etnikinja za ženske, a etnik za muške osobe.

\section{Raščlamba korpusa}

Prema dostupnim podatcima iz zadnjega popisa stanovništva (iz 2011.) otok je Brač administrativno podijeljen na osam samostalnih općina s dvadeset i dva mjesta ${ }^{18}$. Donose se s obzirom na brojnost etnika u njima ${ }^{19}$ :

- Supetar (4 223: Mirca, Splitska, Supetar i Škrip)

- Pučišća (2 263: Gornji Humac, Pražnica i Pučišća)

- Selca (1 860: Novo Selo, Povlja, Selca i Sumartin)

${ }^{14}$ Babić, „Tvorba etnika u dijalektima i u hrvatskom književnom jeziku,“ 146-147.

${ }_{15}$ Primjerice, postavlja se pitanje pisanja etnikinja i etnika bračkih mjesta Mirca i Splitska, a da bi u konačnici bili usklađeni s normom standardnoga jezika. Uz ova dva, takvih je primjera etnika u / na hrvatskome jezičnome prostoru jako puno.

${ }_{16}$ Ankica Čilaš Šimpraga, „Etnici i ktetici u Drniškoj krajini,“ Folia onomastica Croatica, br. 21 (2012): 17.

${ }_{17}$ Petar Šimunović, Uvod u hrvatsko imenoslovlje (Zagreb: Golden Marketing - Tehnička knjiga, 2009), 76.

${ }_{18}$ Jelena Nakićen i Anica Čuka, „Demografski razvoj otoka Brača i sklonost otočana iseljavanju,“ Migracijske i etničke teme, vol. 32, br. 3 (2016): 322-323.

${ }^{19}$ U zagradi je broj stanovnika (godine 2011.) u pojedinoj općini s popisom mjesta koja su u sastavu pojedine općine. 
- Bol (1 693: Bol i Murvica)

- Postira (1 611: Dol i Postira)

- Milna (1 042: Bobovišća, Ložišća i Milna)

- Nerežišća (892: Donji Humac, Dračevica i Nerežišća)

- Sutivan (850).

Radi bolje preglednosti pri izradi popisa etnikinja i etnika bračka su mjesta ${ }^{20}$ podijeljena na ona $u$ unutrašnjosti otoka (10) i na ona uz more $(12)^{21}$ :

- u unutrašnjosti: Dol (130), Donji Humac (165), Dračevica (93), Gornji Humac (275), Ložišća (139), Nerežišća (634), Novo Selo (153), Pražnica (377), Selca (872), Škrip (172)

- uz more: Bobovišća (70), Bol (1 671), Milna (833), Mirca (327), Murvica (22), Postira (1 481), Povlja (344), Pučišća (1 611), Splitska (398), Sumartin (491), Supetar (3 326), Sutivan (850).

Nakon provedenoga terenskoga istraživanja u listopadu 2018. i u ožujku 2019. godine izrađen je korpus koji uključuje pisane oblike za etnikinje i etnike iz promatrana dvadeset i dva bračka mjesta. Svojom su se strukturom i oblikom pokazali kao neotuđivi dio jezika pa donosimo najprije sažet opis i karakteristike bračkih govora za bolje razumijevanje potvrđenih tvorbenih modela etnikinja i etnika.

\section{Jezične osobitosti bračkih govora i tvorbena prilagodba etnika u odnosu na standard}

\subsection{Brački govori i etnici u njima}

Migracijska su kretanja u prošlosti odredila današnju dijalekatsku šarolikost među bračkim mjestima. Zapadni je dio otoka (uglavnom) čakavski (u najvećim mjestima Milna i Sutivan), središnji pak dio, a kao prvi naseljeni prostor otoka, čuva stare jezične elemente $\mathrm{i}$ ishodišni je geografski prostor za sagledavanje ostalih dijelova otoka (i mjesta) i govora (primjerice govori Dračevice, Donjega Humca i Nerežišća). Istočni je dio uglavnom štokavski (primjerice mjesto Sumartin). Broj je stanovnika uvelike danas pao, ali su zabilježena (u minimalnome

\footnotetext{
${ }^{20}$ Od dvadeset i dva (22) bračka mjesta devetnaest (19) ih je jednorječnih, a tri (3) su dvorječna (Donji Humac, Gornji Humac i Novo Selo). Neka su mjesta u množinskome obliku srednjega roda (Bobovišća, Ložišća, Nerežišća i dr.), a neka su u jednini ženskoga roda (Dračevica ili Milna).

${ }^{21}$ U zagradi je broj stanovnika u pojedinome mjestu.
} 
postotku doduše) doseljenja s kopna čime je, naravno, došlo do promjena, a govornika je nekadašnjih autohtonih bračkih govora sve manje. Prije osamdesetak godina veliki je dio bračkih govora opisao Hraste u knjizi Čakavski dijalekat ostrva Brača (1940). Knjiga je to koja je u kasnijim godinama potaknula druge jezikoslovce za nove prinose očuvanju bračkih govora. Od sedamdesetih godina prošloga stoljeća Šimunović aktivno istražuje govore Brača s iznošenjem rezultata u dvjema objavljenim studijama - Ogled jezičnih osobina bračke čakavštine (1975) i Čakavština srednjodalmatinskih otoka (1977). Za potrebe je istraživanja štokavskih govora ranije istražen i opisan govor mjesta Sumartin ${ }^{22}$. Interesa za nove opise bračkih govora ne nedostaje u najnovijim vremenima što potvrđuju istraženi govori mjesta Selaca ${ }^{23}$, Milne $^{24}$, Ložišća ${ }^{25}$, Donjega Humca ${ }^{26}$ i Pražnica ${ }^{27}$ te ostalih koji su se u svojim istraživanjima bavili nekom od posebitosti bračkih govora ${ }^{28}$. Vrijednost i značaj bračkih govora prepoznalo je hrvatsko Ministarstvo kulture dodijelivši im status nematerijalnog kulturnoga dobra.

Za promatranje je tvorbenih oblika bračkih etnikinja i etnika nužno spomenuti i provedena sociolingvistička istraživanja iz druge polovice osamdesetih godina prošloga stoljeća. Potvrdila su kako su migracijska kretanja stvorila razlike u govoru te se na primjerima iz šesnaest promatranih bračkih mjesta predstavlja zanimljiva jezična slika otoka ${ }^{29}$. Iz te je slike moguće dati pojedine odgovore o danas zabilježenoj brojnosti naziva za pojedine etnikinje i etnike iz bračkih mjesta.

Međutim, valja to još jednom napomenuti, onomastika je, posebno unutar nje toponimija, područje gdje se raznolikost u bilježenju oblika

\footnotetext{
22 Petar Šimunović, „Sumartinska onomastika,“ Rasprave Instituta za jezik, br. 1 (1968): 89.

${ }^{23}$ Siniša Vuković, „Akcenatski sustav selačkoga govora - osnovne odlike naglasnoga sustava govora Selaca na otoku Braču,“ Čakavska rič, vol. 34, br. 1-2 (2006): 191; Nataša Šprljan, „Zanaglasne dužine u govoru Selaca na Braču,“ Čakavska rič, vol. 45, br. 1-2 (2017): 55.

${ }^{24}$ Filip Galović, „Fonološke značajke govora Milne na otoku Braču,“ Čakavska rič, vol. 40, br. 1-2 (2012): 87.

${ }^{25}$ Filip Galović, „Jezične osobitosti mjesnoga govora Ložišća na otoku Braču,“ Fluminensia, vol. 25, br. 1 (2013): 181.

${ }^{26}$ Filip Galović, „Govor Donjega Humca,“ Jezikoslovlje, vol. 15, br. 2-3 (2014): 231.

${ }^{27}$ Filip Galović, „Fonološki sustav pražničkoga govora,“ Fluminensia, vol. 29, br. 2 (2017): 91; Zdravka Biočina, Gordana Varošanec-Škarić i Iva Bašić, „Prozodijski sustav Pražnica.“ Fluminensia, vol. 30, br. 1 (2018): 103.

${ }^{28}$ Domagoj Vidović, „Prezimena istočnoga dijela otoka Brača,“ Hrvatski dijalektološki zbornik, br. 18 (2013): 285.

${ }^{29}$ Anita Sujoldžić, Božidar Finka, Petar Šimunović i Pavao Rudan, „Sličnosti i razlike u govorima otoka Brača kao odraz migracijskih kretanja,“ Rasprave: Časopis Instituta za hrvatski jezik i jezikoslovlje, vol. 14, br. 1 (1988): 163.
} 
za etnikinje i etnike najbolje vidi ${ }^{30}$. U toponimima se, iz kojih će kasnije postajati etnici, dobro čuvaju lokalne osobitosti govora. Brački tako govori bilježe da je standardni oblik mjesta Sutivan u govoru Stivan, Povlja su u govoru Povja, a Splitska je Spliska ${ }^{31}$. Oblike Stivan, Povja i Spliska iz govorne stoga prakse valja poštivati u postupcima tvorbe etnikinja i etnika iz spomenutih mjesta.

Dosadašnja su istraživanja područja tvorbe imenica u standardnome jeziku, među kojima se navode i etnici ${ }^{32}$ potvrdila dominaciju imeničke sufiksalne tvorbe. Zabilježeno je u standardnome jeziku da u njoj sudjeluje čak osamdeset i šest (86) imeničkih sufiksa za muški ${ }^{33}$ te dvadeset i jedan (21) imenički sufiks za ženski rod $^{34}$. Uvidom u bračke etnikinje i etnike izdvajaju se vrlo plodni tj. oni koji pokazuju najviši stupanj tvorbene aktivnosti (primjerice za etnike -an(in) (Boljanin, Supetranin i za etnikinje primjerice - $k a$ (Milnaranka, Stivanka, Selka i dr.) $)^{35}$. Istraženi korpus donosi popis etnikinja, a potom popis etnika zabilježenih terenskim radom iz neposrednoga razgovora s lokalnim stanovništvom ${ }^{36}$. Izdvajaju se po kriteriju podjele na ženske (etnikinje) i muške (etnici) čime slabi dosadašnja, u privatnome i u javnome diskursu, dominacija referencijalnoga muškoga roda etnik (koji uključuje ženski i muški rod).

\subsection{Bračke etnikinje}

$\mathrm{Za}$ ženske je osobe (etnikinje) terenskim istraživanjem zabilježeno uz svako mjesto po nekoliko oblika etnikinja. Za neka se mjesta vezuju i po četiri oblika, a svega je nekoliko mjesta uz koja se vezuje jedan do

${ }^{30}$ Petar Šimunović, Bračka toponimija (Zagreb: Golden marketing - Tehnička knjiga, 2004), 156.

${ }^{31}$ Katarina Lozić Knezović, „Obalni toponimi otoka Brača - prilog Bračkoj toponimiji Petra Šimunovića,“ Folia onomastica Croatica, br. 27 (2018): 47.

${ }^{32}$ Barić, Lončarić, Malić, Pavešić, Peti, Zečević i Znika, Hrvatska gramatika (II. promijenjeno izdanje); Silić i Pranjković, Gramatika hrvatskoga jezika za gimnazije i visoka učilišta; Stjepan Babić, Tvorba riječi u hrvatskome književnome jeziku (Zagreb: NZ Globus - HAZU, 2002).

${ }^{33}$ Babić, „Tvorba etnika u dijalektima i u hrvatskom književnom jeziku,“ 148.

${ }^{34}$ Babić, „Tvorba etnika u dijalektima i u hrvatskom književnom jeziku,“ 176-177.

${ }^{35}$ Barić, Lončarić, Malić, Pavešić, Peti, Zečević i Znika, Hrvatska gramatika (II. promijenjeno izdanje), 294.

${ }^{36}$ Prvo je istraživanje provedeno u rujnu 2018. godine i njime je obuhvaćeno četrdeset sedam (47) ispitanika (25 M $+22 \check{Z})$ iz devetnaest (19) mjesta otoka (osim Dola, Bobovišća i Murvice), a drugo u ožujku 2019. godine kada je uključeno novih dvadeset i devet (29) ispitanika $(17 \breve{Z}+13 \mathrm{M})$. Kasnije su uključena i trideset i tri (33) ispitanika $(17 \check{Z}+16 \mathrm{M})$ koji su rođeni i živjeli su određeno vrijeme na Braču, a danas su stanovnici grada Splita. Istraživanjem je ukupno obuhvaćeno sto i devet (109) ispitanika materinskim govorom vezanih uz otok Brač. Na ovome mjestu zahvaljujemo svima koji su pomogli u istraživanju. 


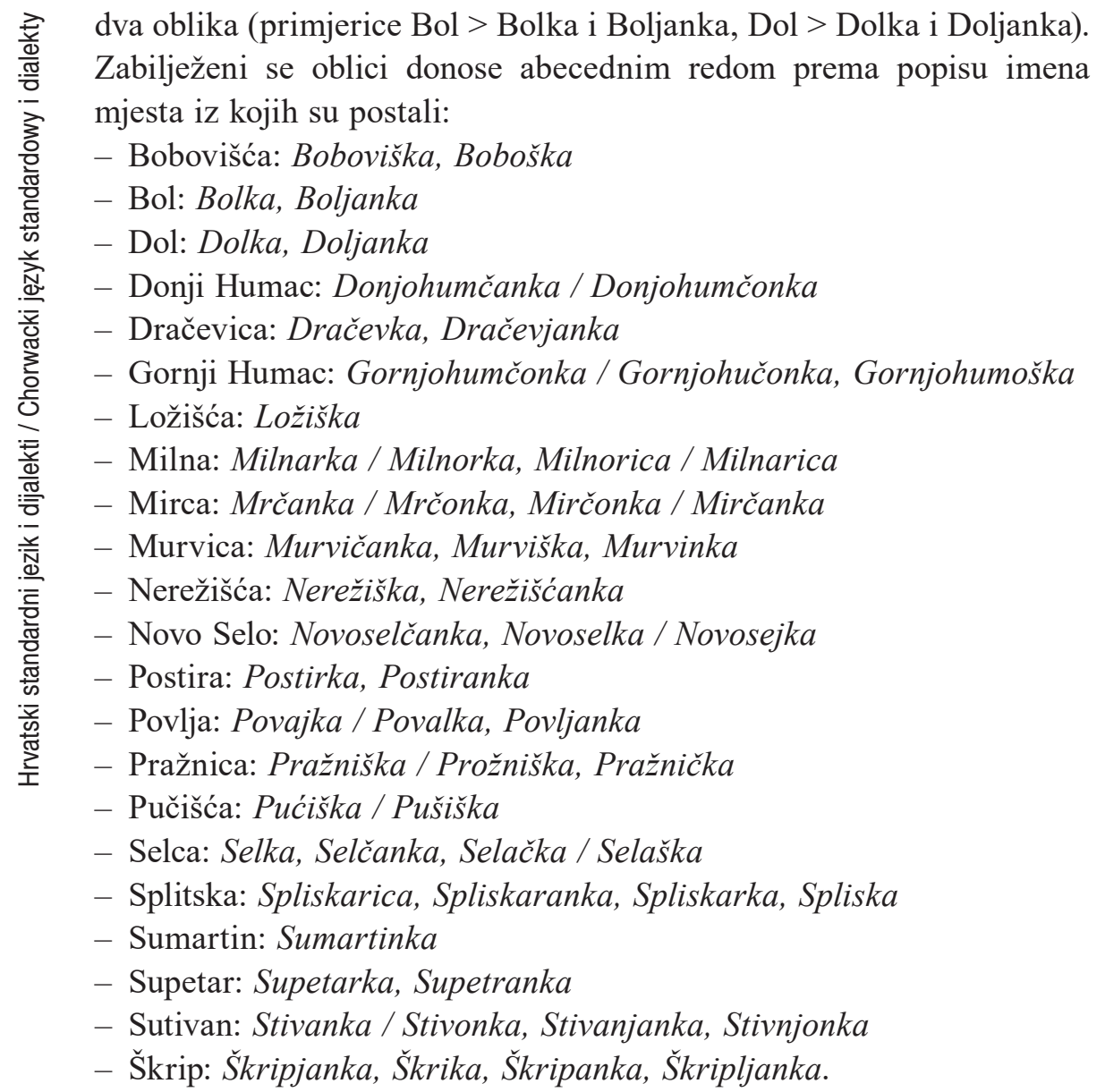

\subsection{Brački etnici}

Kao i za popisane etnikinje i kod etnika se pojavljuje uz pojedina imena mjesta po nekoliko oblika etnika. Također se navode prema istome slijedu, abecednim redom uz imena mjesta iz kojih su izvedeni:

- Bobovišća: Bobovišćanin, Bobovišćan, Bobovjanin / Bobovljanin

- Bol: Boljan, Boljanin / Bolanin

- Dol: Doljanin / Dolanin

- Donji Humac: Donjohumčanin / Donjohumčonin, Donjohumčananin

- Dračevica: Dračevjanin, Dračevjan, Dračevićan

- Gornji Humac: Gornjohumčanin, Hunčanjanin, Gornjohunčonjanin

- Ložišća: Ložišćan, Ložišćanin 
- Milna: Milnaranin, Milnaran

- Mirca: Mrčanjanin / Mirčanjanin, Mrčanin, Mrčanac, Mirčanac

- Murvica: Murvičanin, Murviški

- Nerežišća: Nerežišćanin

- Novo Selo: Novoselčanin, Novosejanin / Novoseljanin

- Postira: Postiran, Postiranin

- Povlja: Povljanin / Povjanin, Povajanin

- Pražnica: Pražnišanin / Pražničanin, Pražniški

- Pučišća: Pućišćanin

- Selca: Selčanin, Selaški

- Splitska: Spliskarin, Spliskavac, Spliskarin

- Sumartin: Sumartinjanin / Sumartinanin

- Supetar: Supetranin, Supetran

- Sutivan: Stivanjanin / Stivonjanin, Stivanac / Stivanjac

- Škrip: Škripjanin.

\subsection{Etnikinje i etnici u postavljanju kroz (preporučenu) standardološku paradigmu}

Iz tvorbe je etnika u standardnome jeziku moguće izdvojiti niz sufiksa, a kako on sam po sebi teži usustavljivanju nemoguće je prihvatiti sve sufikse kojima se bilježe etnikinje i etnici u brojnim hrvatskim lokalnim idiomima ${ }^{37}$. Preporuka je da se, a gdje je god to moguće, koriste za ženske i za muške osobe sufiksi s obzirom na njihovu plodnost ${ }^{38}$. Prema takvoj je preporuci izrađen popis bračkih etnikinja i etnika. Pokazao je da je obrazac plodnih sufikasa iz standardnoga jezika primjenjiv gotovo kod svih zabilježenih etnikinja i etnika. Etnikinje i etnici su postavljeni u okvir plodnih sufiksa za ženske i muške osobe te ih donosimo popisane u nastavku uz mjesto na koje se odnose / kojemu pripadaju:

- Bobovišća: Bobovišćanka i Bobovišćanin

- Bol: Boljanka i Boljanin

- Dol: Doljanka i Doljanin

- Donji Humac: Donjohumčanka i Donjohumčanin / Donjohumčanjanin

- Dračevica: Dračevljanka i Dračevljanin

\footnotetext{
${ }^{37}$ Barić, Lončarić, Malić, Pavešić, Peti, Zečević i Znika, Hrvatska gramatika (II. promijenjeno izdanje), 313.

${ }^{38}$ Mada Babić navodi kako je u hrvatskome standardnome jeziku zastupljeno osamdesetak za muške i dvadesetak sufiksa za ženske osobe, plodni su sljedeći sufiksi: (a) za muške osobe: -ac, -anac i -anin te slabije plodni -čanin i -ak i za (b) ženske osobe: -ica, -inja, -ka i -kinja. Vidi: Barić, Lončarić, Malić, Pavešić, Peti, Zečević i Znika, Hrvatska gramatika (II. promijenjeno izdanje), 313-314.
} 


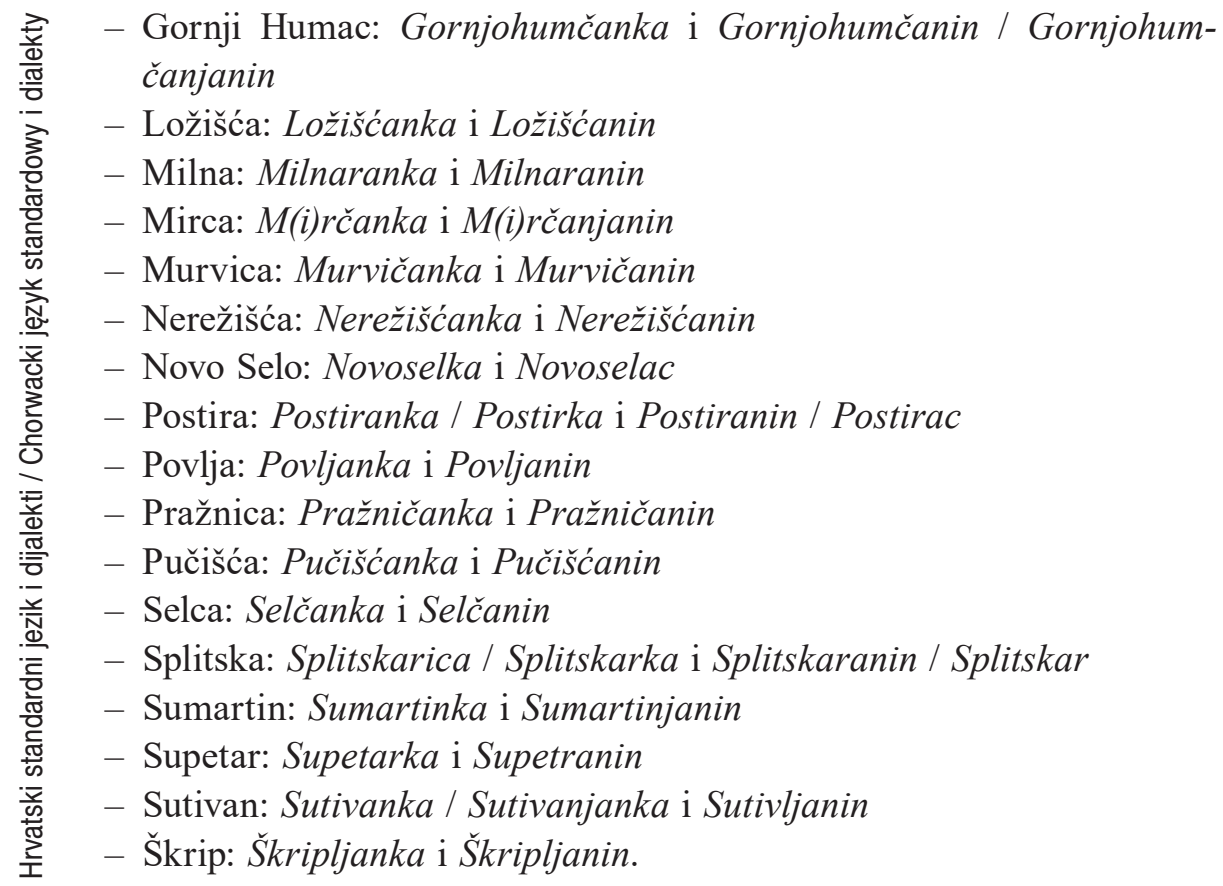

\subsubsection{Etnikinje kroz standardološku paradigmu}

Držeći se pri izradi popisa etnikinja ranijih standardoloških preporuka o korištenju plodnih sufiksa (-ica, -inja, -ka i -kinja) svi su oblici bračkih etnikinja usklađeni s preporukom. Najzastupljeniji je sufiks $-k a$ s brojnim oblicima promjene u osnovi čime se proširuje sufiksalno bilježenje (-(an)ka, -(č)anka, -(j)anka, -(lj)anka). Slabije su zastupljeni ostali plodni sufiksi (primjerice sufiks -ica svega jednom), a ostali plodni nisu zabilježeni (plodni sufiksi -inja i -kinja). Cijeli popis usklađen $\mathrm{s}$ preporukama standardnoga jezika slijedi prema sufiksima:

-ica:

Spli(t)skarica

-ka (-(an)ka, -(č)anka, -(j)anka, -(lj)anka):

Bobovišćanka, Boljanka, Doljanka, Donjohumčanka, Dračevljanka, Gornjohumčanka, Ložišćanka, Milnaranka, M(i)rčanka, Murvičanka, Nerežišćanka, Novoselka, Postiranka / Postirka, Pov(l)janka, Pražničanka, Pučišćanka, Selčanka, Splitskarka, Sumartinka, Supetarka, S(u)tivanka / S(u)tivanjanka, Škri(pljan)ka. 


\subsubsection{Etnici kroz standardološku paradigmu}

Za razliku od etnikinja kod etnika je zastupljen veći broj preporučenih plodnih sufiksa. Postavljajući ih u standardološki obrazac ${ }^{39}$ tri su zabilježena sufiksa na promatranome korpusu (-ac, -anin i -ar). Najplodniji se pokazao u tvorbi bračkih etnika sufiks -anin (zbog okrnjene ili jotirane osnove s modelima -čanin, -(č)an(j)anin, -(j)anin, -(lj)anin). Prema podjeli s obzirom na sufiks koji se pojavljuje popisani su kako slijedi:

$-(a) c$ :

Novoselac, Postirac

-anin (-čanin, -(č)an(j)anin, -(j)anin, -(lj)anin):

Bobovišćanin, Boljanin, Doljanin, Donjohumčanin / Donjohumčanjanin, Dračevljanin, Gornjohumčanin / Gornjohumčanjanin, Ložišćanin, Milnaranin, M(i)rčanjanin, Murvičanin, Nerežišćanin, Postiranin, Povljanin, Pražničanin, Pučišćanin, Selčanin, Splitskaranin, Sumartinjanin, Supetranin, Sutivljanin, Škripljanin

-ar:

Splitskar.

\section{Zaključak}

Prva je namjera ovoga istraživanja bila prikazati etnikinje i etnike u njihovome stvarnome okruženju u kojemu se pojavljuju, dakle, u govorima otoka Brača. Međutim, nakon obavljenoga terenskoga istraživanja i izrađenoga popisa otvorila se prilika na jednome mjestu prikazati odnos i relaciju lokalnoga govora i standarda (kroz promatranje etnikinja i etnika kao središnjega predmeta istraživanja). Pokazali su se vrlo zahvalnim jezičnim materijalom jer su omogućili sagledavanje jezične stvarnosti kroz lokalne govore i kroz standard. Potvrđena je skoro u potpunosti ranija preporuka o plodnim sufiksima za oblikovanje etnikinja i etnika. S druge je pak strane potvrđena djelomična dominacija dijalekata nad standardom. Za nova će istraživanja zasigurno biti zanimljivo proučiti odnos dijalek(a)ta i standarda za: (a) etnikinje i kako ih bilježiti te sa standardom uklopiti u primjerima Spli(t)skarica, Milnaranka, M(i)rčanka, Pov(l)janka, S(u)tivanka (ili S(u)tivanjanka)

\footnotetext{
${ }^{39}$ Barić, Lončarić, Malić, Pavešić, Peti, Zečević i Znika, Hrvatska gramatika (II. promijenjeno izdanje), 313.
} 
i $\breve{S k i(p l j a n) k a ~ i ~ z a ~(b) ~ e t n i k e ~ u ~ p r i m j e r i m a ~ u s k l a đ i v a n j a ~ s a ~ s t a n d a r d o m ~}$ u primjerima Donjohumčanjanin i Gornjohumčanjanin, Milnaranin, M(i)rčanjanin, Pov(l)janin, Splitskaranin, S(u)tivljanin (ili S(u)tivanac) i primjerice oblik Spli(t)skar ${ }^{40}$.

Istraživanje je u potpunosti bilo usredotočeno na promatranje jednoga od najneustaljenijih dijelova u jeziku, a to su etnikinje i etnici u ovome slučaju oni otoka Brača. Ipak, neustaljenosti svojoj unatoč, ponudili su svojim oblicima dodanu vrijednosti koju nose brački govori. Uz to su, bez ikakve sumnje, doprinijeli novome čitanju, pisanju i bilježenju etnika te, dakako, boljemu razumijevanju (stare) teze o onoj elastičnoj stabilnosti (ili gipkoj postojanosti) unutar hrvatskoga standardnoga jezika.

\section{Literatura}

Babić, Stjepan. „Tvorba etnika u dijalektima i u hrvatskom književnom jeziku.“ Onomastica Jugoslavica, br. 6 (1976): 146-185.

Babić, Stjepan. Tvorba riječi u hrvatskome književnome jeziku. Zagreb: NZ Globus - HAZU, 2002.

Barić, Eugenija, Mijo Lončarić, Dragica Malić, Slavko Pavešić, Mirko Peti, Vesna Zečević i Marija Znika. Hrvatska gramatika (II. promijenjeno izdanje). Zagreb: Školska knjiga, 1997.

Biočina, Zdravka, Gordana Varošanec-Škarić i Iva Bašić. „Prozodijski sustav Pražnica.“ Fluminensia, vol. 30, br. 1 (2018): 103-126.

Brozović, Dalibor. „Neki etnici u novom izdanju »Pravopisa«““Jezik, vol. 1, br. 2 (1952): 54-57.

Čilaš Šimpraga, Ankica i Ivana Kurtović Budja. „Etnici i ktetici u kajkavskom narječju.“ Rasprave: Časopis Instituta za hrvatski jezik i jezikoslovlje, vol. 35, br. 1 (2009): 35-52.

Čilaš Šimpraga, Ankica. „Etnici i ktetici u Drniškoj krajini.“ Folia onomastica Croatica, br. 21 (2012): 17-36.

Galović, Filip. „Fonološke značajke govora Milne na otoku Braču.“ Čakavska rič, vol. 40, br. 1-2 (2012): 87-101.

Galović, Filip. „Jezične osobitosti mjesnoga govora Ložišća na otoku Braču.“ Fluminensia, vol. 25, br. 1 (2013): 181-198.

Galović, Filip. „Govor Donjega Humca.“ Jezikoslovlje, vol. 15, br. 2-3 (2014): 231-267.

Galović, Filip. „Fonološki sustav pražničkoga govora.“ Fluminensia, vol. 29, br. 2 (2017): 91-109.

Hraste, Mate. „Čakavski dijalekat ostrva Brača.“ Srpski dijalektološki zbornik, br. 10 (1940): 1-66.

${ }^{40}$ Babić, „Tvorba etnika u dijalektima i u hrvatskom književnom jeziku,“ 150-156. 
Hraste, Mate i Petar Šimunović. Čakavisch-deutches Lexicon, knj. I-III. Köln Beč: Böhlau Verlag, 1979-1983.

Lončarić, Mijo. „Etnik od Koprivnica،“ Jezik, vol. 21, br. 2 (1973): 56-57.

Lozić Knezović, Katarina. „Obalni toponimi otoka Brača - prilog Bračkoj toponimiji Petra Šimunovića.“ Folia onomastica Croatica, br. 27 (2018): 47-69.

Nakićen, Jelena i Anica Čuka. „Demografski razvoj otoka Brača i sklonost otočana iseljavanju.“ Migracijske i etničke teme, vol. 32, br. 3 (2016): 319-351.

Skok, Petar. „Tvorba imena stanovnika od imena naselja i oblasti.“ Jezik, vol. 2, br. 3 (1953): 65-69.

Silić, Josip i Ivo Pranjković. Gramatika hrvatskoga jezika za gimnazije $i$ visoka učilišta. Zagreb: Školska knjiga, 2005.

Sujoldžić, Anita, Božidar Finka, Petar Šimunović i Pavao Rudan. „Sličnosti i razlike u govorima otoka Brača kao odraz migracijskih kretanja." Rasprave: Časopis Instituta za hrvatski jezik i jezikoslovlje, vol. 14, br. 1 (1988): 163-184.

Šimunović, Petar. „Sumartinska onomastika.“ Rasprave Instituta za jezik, br. 1 (1968): 89-121.

Šimunović, Petar. „Ogled jezičnih osobina bračke čakavštine.“ Narodna umjetnost: hrvatski časopis za etnologiju i folkloristiku, vol. 11/12, br. 1 (1975): 497-517.

Šimunović, Petar. „Čakavština srednjodalmatinskih otoka.“ Čakavska rič, br. 1 (1977): 5-65.

Šimunović, Petar. Bračka toponimija. Zagreb: Golden marketing - Tehnička knjiga, 2004.

Šimunović, Petar. Rječnik bračkih čakavskih govora. Supetar: Brevijar, 2006.

Šimunović, Petar. Uvod u hrvatsko imenoslovlje. Zagreb: Golden Marketing - Tehnička knjiga, 2009.

Šprljan, Nataša. „Zanaglasne dužine u govoru Selaca na Braču.“ Čakavska rič, vol. 45, br. 1-2 (2017): 55-76.

Težak, Stjepko. „Etnici i ktetici u pravopisnom rječniku.“ Jezik, vol. 21, br. 2 (1973): 52-56.

Težak, Stjepko. „O temi: toponimi, etnici i ktetici u književnom jeziku.“ Jezik, vol. 22, br. 1 (1974): 1-2.

Vidović, Domagoj. „Prezimena istočnoga dijela otoka Brača.“ Hrvatski dijalektološki zbornik, br. 18 (2013): 285-299.

Vukosavljević, Nikola, Zlatko Perhoč, Božidar Čečuk i Ivor Karavanić. „Kasnoglacijalna industrija lomljenog kamena pećine Kopačine.“ Vjesnik za arheologiju i povijest dalmatinsku, vol. 104, br. 1 (2011): 7-54.

Vuković, Siniša. „Akcenatski sustav selačkoga govora - osnovne odlike naglasnoga sustava govora Selaca na otoku Braču.“ Čakavska rič, vol. 34, br. 1-2 (2006): 191-201.

\section{Formation of Demonyms of the Island of Brač}

Summary: The term demonym (cro. etnik) is used in the Croatian linguistic bibliography to denote ,the name of a person (a male or a female) living or having origins in an inhabited place (oyconym), region, country, state and continent" (Babić, 
1976: 145). Previous researches on the formation of demonyms in the standard (Barić, 1997; Silić and Pranjković, 2005) and some regional varieties (Šimunović, 2006; Čilaš Šimpraga and Kurtović Budja, 2009) of the Croatian language suggest that they are most frequently formed by the means of suffixation. Namely, 86 suffixes for male and 21 suffixes for female gender have been identified in the standard Croatian language. The aim of this paper is to present and analyse a corpus of demonyms of the Central Dalmatian island Brač. The corpus is a result of a field research conducted in September 2018 and March 2019. The research shows that there are 22 inhabited places on the island of Brač whose names were used to obtain about forty demonyms for each gender. For the purposes of this paper, they were subsequently recorded, verified, listed and analysed in terms of the type of their formation. Since the analysis of demonym formation revealed instances of multi-layered language variation, this paper will present some special features of local speeches recorded directly on the spot through the examples of interesting types of formation of demonyms for both genders. The aim of this paper is, therefore, two-fold: to preserve the demonyms from oblivion (since some of the places on the islands of Brač may soon be abandoned and uninhabited), and to systematize the demonyms of Brač in line with the models of demonym formation established for the standard Croatian language.

Keywords: demonyms, formation of demonyms, dialect, local speech of island Brač 